Diabetologia 9, 20-24 (1973)

(C) by Springer-Verlag 1973

\title{
Erythrocyte Aggregation in Relation to Diabetic Retinopathy
}

\author{
N.J. van Haeringen, J.A. Oosterhuis, J. Terpstra and E. Glasius \\ Eye Clinic, University Hospital, Amsterdam, Eye Clinic, University Hospital, Leyden, Diabetes Department, Uni- \\ versity Hospital, Leyden, The Netherlands
}

Received: October 3, 1972, accepted: December 2, 1972

Summary. Erythrocy te aggregation, plasma fibrinogen concentrations and serum protein fractions have been studied in 19 diabetic patients without retinopathy, 18 pationts with retinopathy and 41 non-diabetic controls. Significant differences in the parameters were observed between diabetics and controls. The differences between the diabetics with and without retinopathy were not significant. - The role of abnormal erythrocyte aggregation in the development of diabetic retinopathy is discussed. - Striking parallels were found with similar findings concerning platelet aggregation in diabetics.

Key words: Diabetes, retinopathy, erythrocyte aggregation, fibrinogon.

\section{Introduction}

Ditzel and Moinat (1959) observed cell aggregates in the conjunctival vessels in diabetics. They found that the tendency to aggregation was due to a coating of the erythrocytes related to elevated plasma fibrinogen and globulin levels in their patients. Skovborg et al. (1966) found increased blood viscosity in long term diabetics, which they ascribed to the.formation of erythrocyte aggregates, caused by interaction of fibrinogen and globulins at high concentration with the erythrocytes. Since erythrocyte aggregation or blood sludging may be a pathogenetic factor in diabetic retinopathy, we investigated erythrocyte aggregation in groups of controls and diabetics with and without retinopathy. early in life in diabetic patients, interfering with both the results of erythrocyto aggregation measurement and the evaluation of the fundus lesions. Two groups of diabetie patients were seloctod.

Group $A$ consisted of 19 diabetics without retinopathy, 6 males and 13 females. Their averago age was 24 years (range $12-38$ years)

Group $B$ consisted of 18 diabetics with retinopathy, 12 males and 6 females. Their average age was 32 years (range 19-47 years).

The two groups of patients were considered to be comparable because previous studies had shown that the results of erythrocyte aggregation measurements are unaffected by differences in sex or age. The presence or absence of diabetic retinopathy was established both from ophthalmoscopic observation and from a fluoresceinangiographic study of pictures of the macular and porimacular areas of the rotina. In diabetic patients determination of ery throcyte aggregation was performed twice, with an interval of 6-12 months, to find out if any

Table 1. Syllectometry values and plasma protein concentrations in controls and diabetics

\begin{tabular}{|c|c|c|c|c|c|}
\hline & Controls & Group A & $\begin{array}{l}\text { Diabetics } \\
\text { after } \\
6-12 \text { mo }\end{array}$ & Group B & $\begin{array}{l}\text { after } \\
6-12 \mathrm{mo} \\
\end{array}$ \\
\hline Number & 41 & 19 & 19 & 18 & 18 \\
\hline $\begin{array}{l}\text { Rate }\left(\mathrm{sec}^{-1}\right) \\
\text { Corrected rate } \\
\text { Defibrinated rate } \\
\text { Fibrinogen rate } \\
\text { Haemaccel rate }\end{array}$ & $\begin{array}{l}0.21 \pm 0.01 \\
0.22 \pm 0.01 \\
0.07 \pm 0.005 \\
0.15 \pm 0.005 \\
0.29 \pm 0.01\end{array}$ & $\begin{array}{l}0.26 \pm 0.02 \\
0.27 \pm 0.02 \\
0.09 \pm 0.01 \\
0.18 \pm 0.01\end{array}$ & $\begin{array}{l}0.25 \pm 0.02 \\
0.26 \pm 0.02 \\
0.08 \pm 0.01 \\
0.18 \pm 0.01 \\
0.28 \div 0.01\end{array}$ & $\begin{array}{l}0.29 \pm 0.02 \\
0.31 \pm 0.02 \\
0.10 \pm 0.01 \\
0.21 \pm 0.01\end{array}$ & $\begin{array}{l}0.26 \pm 0.02 \\
0.29 \pm 0.02 \\
0.10 \pm 0.01 \\
0.19 \pm 0.01 \\
0.27 \pm 0.01 \\
\end{array}$ \\
\hline Fibrinogen $\mathrm{g} / \mathrm{l}$ & $2.8 \pm 0.1$ & $3.7 \pm 0.1$ & $3.6 \pm 0.1$ & $3.6 \pm 0.2$ & $3.6 \pm 0.2$ \\
\hline
\end{tabular}

\section{Clinical material}

Controls consisted of 41 non-diabetic volunteers, 19 males and 22 females, with an average age of 29 years (range 17-49 years). From the diabetes Out-patient Dopartment of Leyden University Hospital patients wero selected with the juvenile onset type of diabetes. Selection of this material seemed reasonablo if wo were to prevont senile vascular changes, which may develop relatively change in aggregation tendency had occurrod within this period.

\section{Methods}

Blood was withdrawn by venepuncture. One sample was anticoagulated with lithium-E.D.T.A. $\quad(0.8 \mathrm{mg} / \mathrm{ml}$ blood). Anothor sample was defibrinated by shaking with glass beads for $10 \mathrm{~min}$. 


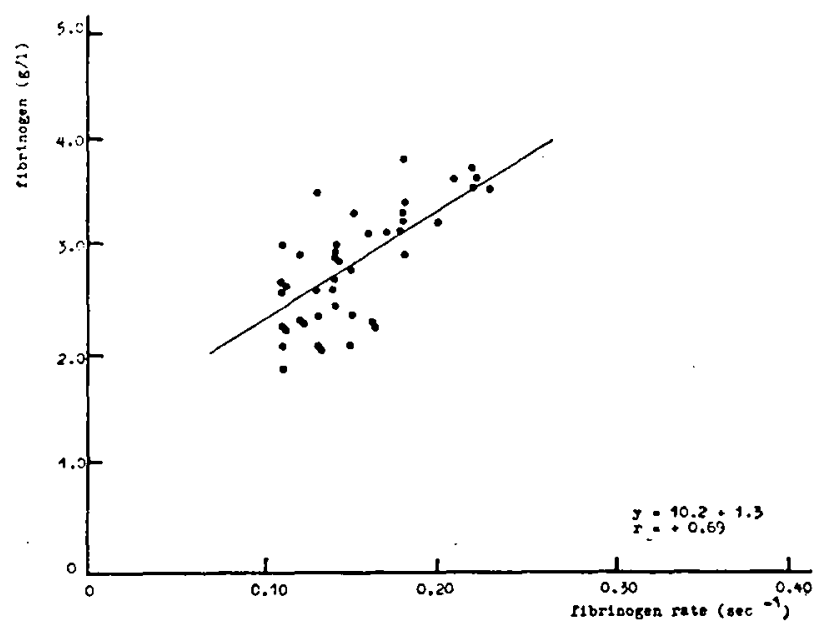

Fig. 1a. Scattergram of the relation between fibrinogen concentration and fibrinogen rate in the controls. Circles and broken line indicate values after $6-12 \mathrm{mo}$.

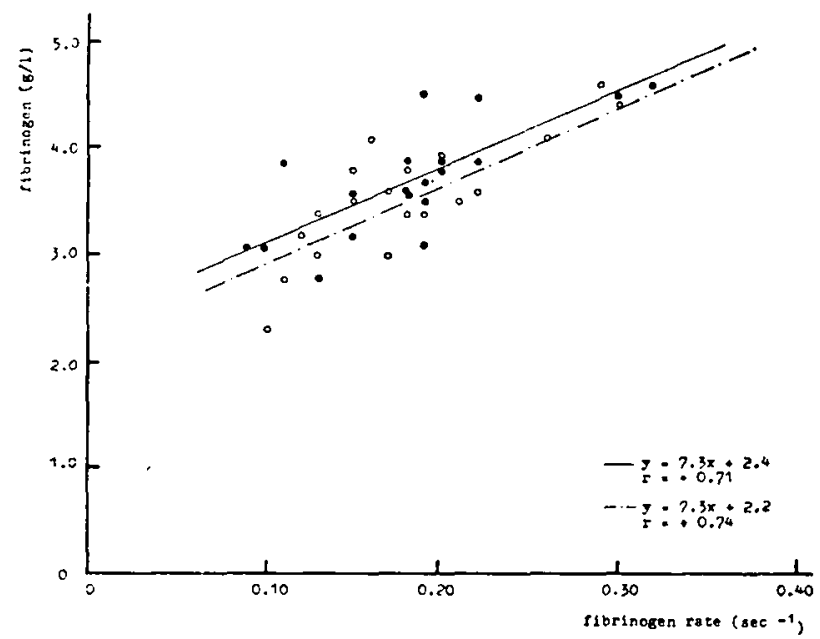

Fig. 1 b. Scattergram of the relation between fibrinogen concentration and fibrinogen rate in group A. Circles and broken line indicate values after 6-12 mo. roflecting surface area of the erythrocytes is then diminished by the formation of rouleaux.

The intensity of the reflected light is measured by a photo-electric cell and the whole process of reflection decrease is recorded. From the curve thus obtained the half-time of reflection decrease is calculated and this is then used as a measure of the rate of rouleaux formation. The method has been described in detail elsewhere (Van Haoringon and Glasius, 1970).

The rate of rouleaux formation is expressed in the reciprocal value of the half-time $\left(\mathrm{sec}^{-1}\right)$.

The corrected rate is the rate in blood after correction of the haemoglobin concentration to $15 \mathrm{~g}$ percent.

The defibrinated rate is the corrected rate of defibri. nated blood.

The fibrinogen rate is the rate obtained by subtraction of the denbrinated rate from the corrected rate. It is the theoretical value of the rate of rouleaux formation caused by the presence of fibrinogen alone.

The "Haemaccel" rate is the rate of a 40 percent orythrocyte suspension in Haemaccel. Haemaccel is a commercially available plasma expander containing 3.5 percent of a modified gelatin.

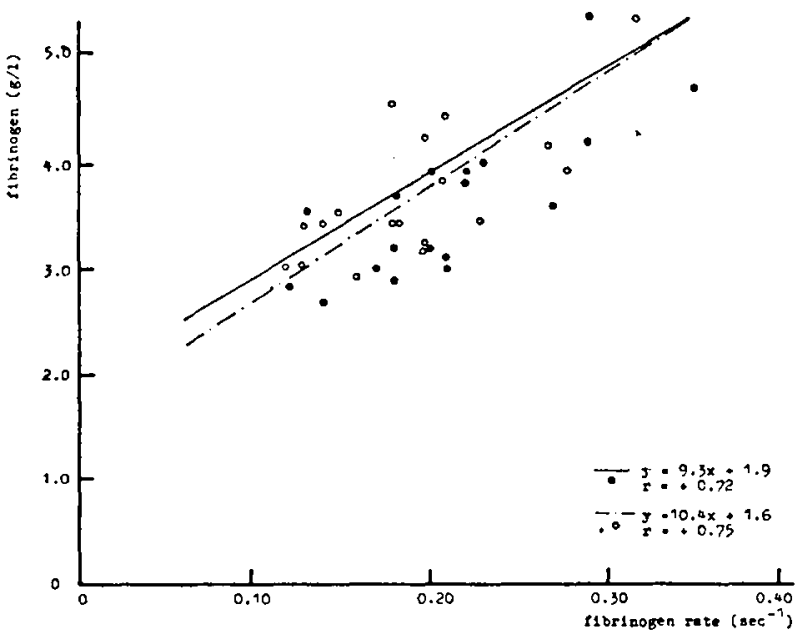

Fig. 1c. Scattergram of the relation between fibrinogen concentration and fibrinogen rate in group B. Circles and broken line indicate values after 6-12 mo.

Table 2. Syllectometry values and serum protein concentrations in controls and diabetics

\begin{tabular}{|c|c|c|c|c|c|}
\hline & Controls & Group A & $\begin{array}{l}\text { Diabetics } \\
\text { after } \\
6-12 \text { mo }\end{array}$ & Group B & $\begin{array}{l}\text { after } \\
6-12 \mathrm{mo}\end{array}$ \\
\hline Number & 41 & 19 & 19 & 18 & 18 \\
\hline $\begin{array}{l}\text { Defibrinated rate }\left(\mathrm{sec}^{-1}\right) \\
\text { Serum protein }(\mathrm{g} / \mathrm{l}) \\
\text { albumin } \\
\alpha_{1}-\text { globulin } \\
\alpha_{2} \text {-globulin } \\
\beta \text {-globulin } \\
\gamma \text {-globulin }\end{array}$ & $\begin{aligned} 0.07 & \pm 0.005 \\
73.6 & \pm 1.5 \\
49.2 & \pm 1.0 \\
2.5 & \pm 0.1 \\
5.5 & \pm 0.2 \\
5.7 & \pm 0.2 \\
10.3 & \pm 0.5\end{aligned}$ & $\begin{array}{l}0.09 \pm 0.01 \\
72.5 \pm 1.2 \\
44.7 \pm 0.7 \\
2.8 \pm 0.2 \\
7.4 \pm 0.3 \\
6.5 \pm 0.3 \\
11.0 \pm 0.5\end{array}$ & $\begin{array}{l}0.08 \pm 0.01 \\
72.0 \pm 1.0 \\
44.5 \pm 0.6 \\
2.5 \pm 0.1 \\
7.0 \pm 0.3 \\
7.4 \pm 0.4 \\
10.5 \pm 0.5\end{array}$ & $\begin{array}{r}0.10 \pm 0.01 \\
68.3 \pm 0.9 \\
43.2 \pm 0.7 \\
2.4 \pm 0.1 \\
6.8 \pm 0.3 \\
6.0 \pm 0.2 \\
10.0 \pm 0.3\end{array}$ & $\begin{array}{r}0.10 \pm 0.01 \\
71.5 \pm 1.1 \\
45.5 \pm 1.0 \\
2.3 \pm 0.1 \\
6.8 \pm 0.2 \\
6.5 \pm 0.2 \\
10.4 \pm 0.4\end{array}$ \\
\hline
\end{tabular}

Erythrocyte aggregation was determined by syllecto. metry (Brinkman et al., 1963). Syllectometry is a method based on measurement of the decrease in reflection of red light which occurs within 60 seconds after abruptly stopping the stirring of an erythrocyte suspension. The
Fibrinogen was determined by applying the biuret reaction to the fibrin clot according to Ware's method (1947).

Serum protein fractions were determined by eloctro. phoresis on cellulose acetate (Cellogel). Strips were stained 
with ponceau-S and the fractions were cut off and determined colorimetrically after dissolving in an appropriate volume of acetic acid 80 percent.

Haemoglobin was determined by the haemiglobincyanide method (Van Kampen and Zijlstra, 1961).

\section{Results}

\section{Syllectometry values and fibrinogen concentration}

In both groups of diabetics the mean values of the rate rouleaux formation, the corrected rate, the defibrinated rate, the fibrinogen rate and the fibrinogen concentration were higher than in the controls (Table 1). The significance varied from $p<0.001$ to $p<0.05$, except for the value of the defibrinated rate in group $A$ after $6-12$ months, when $p<0.40$.

The correlation in each group between fibrinogen concentration and fibrinogen rate is shown in the

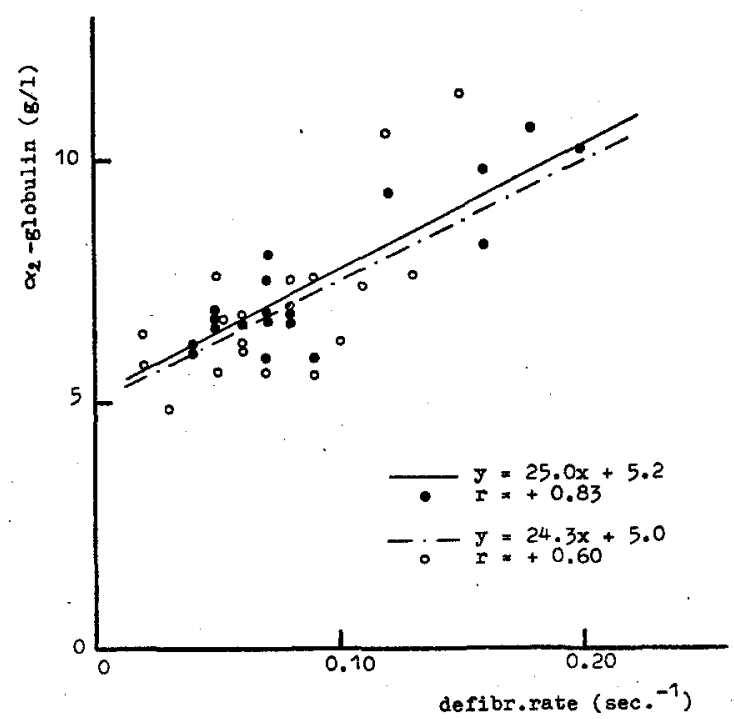

Fig. 2a. Scattergram of the relation between serum $\alpha_{2}$. globulin concentration and defibrinated rate in group A. Circles and broken line indicate values after 6-12 mo.

scattergrams in Fig. 1. A satisfactory regression was computed.

Within one group of diabetics only small, if any, differences in the average values of fibrinogen rate and fibrinogen concentration were found after 6-12 months, in spite of a sometimes considerable individual difference in fibrinogen rate and fibrinogen concentration in one subject after 6-12 months.

\section{Syllectometry values and serum protein fractions}

In defibrinated blood of both groups of diabetics a positive correlation exists between the defibrinated rate and the serum $\alpha_{2}$-globulin concentration (Fig. 2).

In group $A$ there is also a correlation between the defibrinated rate and the $\not \dot{p}$-globulin concentration. In group B, however, no such correlation could be de- monstrated, because of the rather narrow range of $\beta$-globulin levels observed.

For the same reason no correlation could be de. monstrated between the defibrinated rate and the serum globulin concentrations in the controls.

In both groups of diabetics the serum $\alpha_{2}$-globulin concentration was significantly higher $(p<0.001)$ and the albumin concentration significantly lower than in the controls $(p<0.001)$.

\section{Syllectometry values in Haemaccel}

There was no significant difference in the mean values of the Haemaccel rate between the two groups of diabetics or between the diabetics and controls.

Although in group $\mathbf{B}$ the rate, the corrected rate, the defibrinated rate and the fibrinogen rate are higher no significant difference could be demonstrated in these values between groups $A$ and $B$.

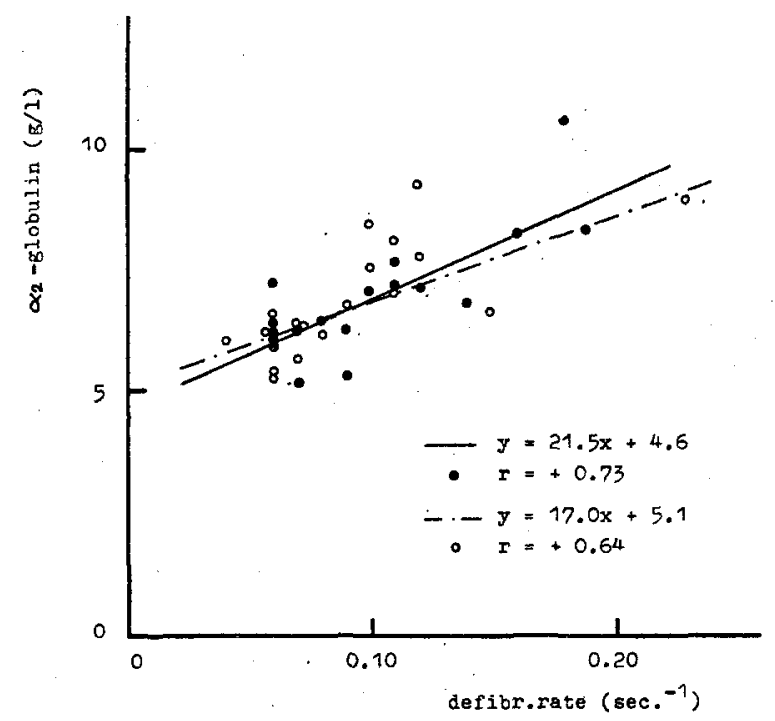

Fig. 2 b. Scattergram of the ralation between serum $\alpha_{2}$. globulin concentration and defibrinated rate in group $\mathbf{B}$. Circles and broken line indicate values after 6-12 mo.

\section{Discussion}

The relatively fast rate of rouleaux formation, as deduced from syllectometry, represents the first step in the rather slowly developing series of events in erythrocyte aggregation in vitro occurring during blood sedimentation (Thorsen and Hint, 1950).

Plasma fibrinogen is the main component governing the rouleaux formation of erythrocytes in the controls and in the diabetics, as is shown in Table 1 and Fig. 1. Within the age limits of our groups there is no increase of plasma fibrinogen with age, as was found by Ogston and Ogston (1966). Defibrination results in a rate of rouleaux formation that is but a third to a quarter of the rate in whole blood. Sometimes no rouleaux formation takes place in defibrinated blood (van Haeringen and Glasius, 1970). This is in accord- 
ance with the greatly reduced viscosity values in defibrinated blood found by Merrill et al. (1963). The effect of fibrinogen upon erythrocyte aggregation also can be studied with pure fibrinogen, thus excluding the effects of other proteins (Wells et al., 1964 and Chien et al., 1967). Cell aggregation was observed through a microscope and semiquantitative estimates were made from photomicrographs.

The existence of an erythrocyte factor (Hirschboeck, 1947 and Jansonius and Zijlstra, 1965) could not be demonstrated in Haemaccel as standard fluid. Haemacel was preferred over a standard plasma pool or fibrinogen solution, since it is commercially available as a sterile solution of constant composition and is stable at room temperature. Our findings that syllectometry values are significantly higher in diabetic patients than in controls are in agreement with the results of Ditzel and Moinat (1955), who found that intravascular erythrocyte aggregation in the con. junctival vascular bed occurs more frequently in diabetic patients than in non-diabetic controls. They found a relationship between the intensity of erythro. cyte aggregation and the degree of retinopathy and nephropathy. We also found higher syllectometry values in diabetic patients with retinopathy, but the difference, as compared with diabetic patients without retinopathy, was not statistically significant. This may be beoause there is not an essential difference between the two groups of diabetic patients, but only a gradual difference between those not yet having developed retinopathy and those with retinopathy, the latter group gradually increasing at the expense of the former, until almost all patients have developed retinopathy after two decades of manifest diabetes (Vink, 1969).

Repeated investigation after the relatively short period of 6-12 months gave mean values that again showed no significant difference between the two groups of diabetic patients.

If the abnormal erythrocyte aggregation in blood of diabetics, as shown in our syllectometry results, should take place also in vivo, then vascular occlusion at the level of the microcirculation might occur, thus promoting the development of diabetic retinopathy. This fits in well with the clinical observation that in high viscosity syndromes a retinopathy may develop which in some respects resembles diabetic retinopathy. This may, for instance, be seen in retinal vein thrombosis, where fluorescein angiography of the fundus may show the development of many microaneurysms, areas of capillary closure and neovascularisation (Oosterhuis and Vink, 1968).

Dintenfass et al. (1966) found a high viscosity syndrome due to an excessive aggregation of the erythrocytes in various thrombotic states. Van Haeringen (to be published) found abnormal syllectometry values in elderly patients with various thrombotic disorders of the retina.
The results presented here show striking parallels with the findings of Heath et al. (1971) that platelet aggregation in vitro is increased in diabetics with deteriorating retinopathy. However, it has to be emphasized that the pathogenesis of diabetic angiopathy is a problem of great complexity, in which increased erythrocyte aggregation tendency is only one of the aggravating factors.

\section{References}

1. Brinkman, R., Zijlstra, W.G. and Jansonius, N.J.: Quantitative evaluation of the rate of rouleaux formation of erythrocytes by measuring light reflection ("syllectomotry"). Proc. kon. ned. Akad. Wet. 66, 412 (1963).

2. Chien, S., Usami, S., Dellenback, R.J., Gregersen, M.I., Nanninga, L.B. and Guest, M.M.: Blood viscosity: influence of erythrocyte aggregation. Science 157, 829 (1967).

3. Dintenfass, L., Julian, D. and Miller, G.: Viscosity of blood in normal subjects an in patients suffering from coronary occlusion and arterial thrombosis. Amer. Heart. J. 7, 587 (1966).

4. Ditzel, J. and Moinat, P.: Lipoproteins and glycoproteins in diabetic subjects. J. Lab. clin. Med. 57, 873 (1959).

5. Haeringen, N.J. van and Glasius, E.: The relation between rouleaux formation in blood and fibrinogen content in plasma. Clin. chim. Acta 29, 55 (1970).

6. Heath, H., Brigden, W.D., Canever, J.V., Pollock, J., Hunter, P.R., Kelsey, J. and Bloom, A.: Platelet adhesiveness and aggregation in relation to diabetic retinopathy. Diabetologia 7, 308 (1971).

7. Hirschboeck, S.: Lecithin and the erythrocyte factor in the blood sedimentation phenomenon. Blood 2, 578 (1947).

8. Jansonius, N.J. and Zijlstra, W.G.: Various factors influencing rouleaux formation of erythrocytes, studied with the aid of syllectometry. Proc. kon. ned. Akad. Wet. 68, 121 (1965).

9. Kampen, E.J. van and Zijlstra, W.G.: Standardisation of haemoglobinometry II. The haemiglobincyanide method. Clin. chim. Acta 6, 538 (1961).

10. Merrill, E.W., Cokelet, G.C., Britten, A. and Wells, R.E.: Non-Newtonian rheology of human blood Effect of fibrinogen deduced by "subtraction". Cir. culat. Res. 13, 48 (1963).

11. Ogston, C.M. and Ogston, D.: Plasma fibrinogen and plasminogen levels in health and in ischaemic heart disease. J. clin. Path. 19, 352 (1966).

12. Oosterhuis, J.A.: Fluorescein fundus photography in retinal vein occlusion. Perspectives in Ophthalmology, p. 29. Rotterdam: (Excerpta Medica Foundation), (1967).

13. Skovborg, F., Nielsen, Aa. V., Schlichtkrull, J. and Ditzel, J.: Blood-viscosity in diabetic patients. Lancet 1966 I, 129.

14. Thorsen, G. and Hint, H. : Aggregation, sedimentation and intravascular sludging of erythrocytes. Acta chir. scand. 154 (1950). 
15. Vink, R.: Fluorescein angiography in diabetic retinopathy. Leiden: Thesis (1969).

16. Ware, A.G., Guest, M.M. and Seegers, W.H.: Determination of fibrinogen in plasma by applying the biuret reaction to the fibrin clot. Arch. Biochem. 13, 231 (1947).

17. Wells, R.E., Gawronski, T.H., Cox, P.J. and Pepera; R.D.: Influence of fibrinogen on flow properties of erythrocyte suspensions. Amer. J. Physiol. 207, 1035 (1964).

Dr. N.J. van Haeringen

University Eye Clinic

Wilhelmina Gasthuis

1 e Helmersstraat 104

Amsterdam

The Netherlands 